\title{
Portugal and Angola - the politics of a troubled media relationship
}

\author{
Luís António Santos \\ Communication and Society Research Centre, University of Minho \\ lsantos@ics.uminho.pt
}

Keywords: Angola, Lusophony, media policy, political communication, Portugal, regulation

In his last text of 2016, published on Christmas day, the editor of Angola's official newspaper, Jornal de Angola, wrote a 'message of harmony' where he chose to focus on diplomatic relations with the former colonial power. José Ribeiro's reading was clear: "Forty one years after independence the Portuguese elites still treat us impolitely as if we were their slaves" (Ribeiro, 2016). This posture would be reinforced precisely a week later in the first editorial of 2017: "Angola will not cease to be an independent country (...) no longer willing to accept mouldy neo-colonial impositions from abroad" (Ribeiro, 2017).

Rather than fortuitous episodes these bellicose statements are a sign that a postcolonial reframing of the relationship between the two countries is - despite the relevance of economic ties ${ }^{1}$ - still far from attained but also a sign of how the media have become strategically relevant in this on-going political process.

Following the definitive end of the civil war in in Angola in 2002 (with the death of Jonas Savimbi, and UNITA's ensuing transformation into a political party) a small elite began to accumulate wealth in haste. Much in a manner close to that described by Bayart - through a 'politics of the belly' oriented by 'strategies of offering' (1993, pp. 228-259) - a restrict group of people, formed by members of the State, ruling party and military apparatuses started to take control of oil and precious minerals extraction income and progressively extended its interests into other areas (Costa, 2014, p. 126). The elite itself acknowledged this process with a very carefully chosen and ideologically charged wording - a "legitimate primitive accumulation of capital"2 - and the whole procedure has even been applauded by the President, José Eduardo dos Santos, in a 'State of the Nation' address to Parliament in October 2013: "The primitive accumulation of capital in western countries took place hundreds of years ago and by then the rules of the game were different. The primitive accumulation of capital which is now occurring in Africa should be adapted to our own reality" (Santos, 2013, p. 13).

This impetus soon developed a necessity to expand and diversify and starting in earnest from 2007 onwards it targeted Portugal's ailing building, real estate and banking businesses as apt investment opportunities. In the decade that followed the end of the civil war Angolan investment in Portugal increased by 35 times reaching $126 \mathrm{M} €$ in 2012 (Jornal de Notícias, 2012-08-22); by 2013 the total Angolan investment in Portugal was estimated at around 6B€ (Renascença, 2013-07-09).

\footnotetext{
${ }^{1}$ Portugal has consistently been among the two main exporters to Angola since 2011 (China is the number one since 2013) and Angola integrates the top ten of exporters to Portugal in the same period (AICEP, 2016, December).

${ }^{2}$ Interview with minister Aguinaldo Jaime in Diário Económico, 08-05-2008 (quoted in Costa et al., 14)
} 
A debilitated media sector would be directly targeted from 2009 onwards. The external imposition of austerity measures following the 2008 financial crisis in Portugal would remove an estimated $29 \mathrm{~B} €$ from the economy between 2011 and 2015 (Silvestre \& Cruz, 2014-03-25) and that would severely impact the consumption indexed activities of a sector already facing digitization induced problems since 2004. Indeed, "in the timeframe of a decade the Portuguese advertising market was cut by nearly half (from $720 \mathrm{M} €$ in 2007 to $390 \mathrm{M} €$ in 2013) and the combined revenues of the three publicly traded Portuguese media groups (Impresa, Media Capital and Cofina) were cut by 35\%" (Sousa \& Santos, 2014, p. 56). These three groups suffered combined losses of $80 \mathrm{M} €$ in 2008 and $29 \mathrm{M} €$ in 2011 , only partially compensated by gains of $11 \mathrm{M} €$ in 2012 and $25 \mathrm{M} €$ in 2013 (Nobre, 2014).

Newshold, a group held by an Angolan capital company based in Panama, entered the Portuguese media market by acquiring ailing weekly Sol in 2009. By the end of 2011 it also held $15 \%$ of Cofina (the group which has the biggest national daily, Correio da Manhã) and a smaller position at Impresa, Portugal's oldest media group. In 2014 it also acquired daily $i$.

As of late 2013 a new Angolan investor emerged; António Mosquito, almost simultaneously acquired $66,7 \%$ of one of Portugal's biggest construction companies, Soares da Costa ${ }^{3}$, and a controling position at one of Portugal's four biggest media groups, Global Media Group (Controlinveste before being renamed) ${ }^{4}$.

Isabel dos Santos, the daughter of the Angolan president - the first woman billionaire in Africa, according to Forbes magazine ${ }^{5}$-, does not have any direct interest in Portuguese media groups but her presence is clear, either through the relevant participation in major banking institutions (like Millenium BCP, which has a 15\% stake at Global Media Group), through major partnerships with media outlets controlling groups (like SONAE, the owner of Público), or through extensive influence in the telecommunications sector, as the largest individual shareholder of the two biggest national operators, Portugal Telecom and Zon Multimedia (Figueiras \& Ribeiro 2013, p. 518).

Two relevant factors should be mentioned. Firstly, most of these operations were conducted under the rule of a neo-liberal government in Lisbon (2011-2015), which actively promoted a non-interventionist stance towards foreign investments whilst reducing regulatory authorities' operational budgets. Furthermore, the Portuguese regulatory framework is focused on nominal ownership and would thus be ill prepared to act upon acquisitions promoted under an 'authoritarian-corporatist' media model strategy (Sparks, 2010, p. 552). Secondly, the 'meeting of minds' between shareholders and managers of Portuguese media businesses in dire straits and some key elements in Angola's ruling elite was actively promoted by influential politicians with vested interests. In a broader analysis of these very particular 'interchanges' between 2007 and 2014, Costa et al. would indicate that 27 former members of Portuguese governments found themselves in the boards of companies and groups operating mainly in Angola (strictly Angolan, of Angolan capital majority, of mixed Angolan-Portuguese capital or of Brazilian-Angolan capital), and that 120 other politicians accessed positions in 17 distinct Portuguese economic groups with Angolan capital (2014, pp. 97-101).

\footnotetext{
${ }^{3}$ http://www.publico.pt/economia/noticia/antonio-mosquito-passa-a-chairman-da-soares-da-costa$\underline{1623506}(24-03-2014)$.

${ }^{4} \mathrm{http}: / / \mathrm{w} w w . d i n h e i r o v i v o . p t / E m p r e s a s / A r t i g o / C I E C O 296869 . h t m l$ ?page $=0$ (25-03-2014).

5 http://www.forbes.com/profile/isabel-dos-santos/ (25-03-2014).
} 
A propitious combination of factors - a debilitated media sector in desperate need of capital, a mainstream political class casting a more than benevolent eye over all opportunities of foreign investment, and an Angolan elite eager to diversify - paved the way for the creation of a perception of change in Portugal-Angola relations. The remit was rather simplistic but it produced visible effects at least until 2013 - a new image was to be put forward, based on mutually beneficial increased economic and financial interdependence and also on a rather dated but still effective colonial reminiscence sentiment (Candeias et al., 2016). Angola was presented in Portuguese media as both a new Eldorado and as the opportunity for a nostalgic return to the 'childhood homeland' of some Portuguese (André \& Fernandes, 2015-11-11). A recent study of news production in four major Portuguese newspapers on PortugalAngola relations between 2008 and 2015 established precisely that economic related issues and migration were the main topics of news production until 2013 and that most of it was highly positive in tone: "the Portuguese go to Angola in search of job opportunities to escape the European crisis and to earn better salaries and the Angolans come to Portugal to get higher education degrees or as tourists" (Hayes, 2016, p. 31).

This almost blissful narrative found positive reverberations in both Lisbon and Luanda. In a book trying to answer the question 'Who really owns Portugal?' Alves \& Sarmento would write about the value of such a change for the Angolan elite: "they are much more sensitive to what the Portuguese media say about them than to what is written elsewhere (...) hence the temptation to exert control" $(2015$, p. 59). In a telling comment on his personal blog in late 2013 the former Angolan prime-minister (1992-1996) and first Executive Secretary of the Community of Portuguese Language Countries (1996-2000), Marcolino Moco, would write much in the same manner: "In Portugal, I see exactly what I predicted. Businessmen, diplomats and even intellectuals, fall to their knees asking Portuguese newspapers not to touch the little problems of Angolan dignataries, like the world known issues with General Bento Kangamba. For that to be mentioned in France, in Brazil, in the USA or elsewhere is OK, but not here in Portugal, "oh no, please no""6. On the Portuguese side, support would come from the government itself. Miguel Relvas, minister for Parliamentary Affairs, would write in Jornal de Angola about the common language as a bond of fraternity and as a "promoter of affections"7.

Yet the second half of 2013 would precisely be the moment this construction started to show its immense frailty. On the one hand, signs of a decline in Angola's economic growth rate, substantially due to the fall in oil prices (Galope, 2015-10-29), would open up space to the appearance of less favourable economic news in Portuguese media (more prominently in Visão, Expresso or SIC television, part of Impresa group), and on the other hand the political handling of a specific legal investigation in Portugal, involving leading Angolan figures, would prompt a very visible diplomatic tension. The investigation had been revealed by Expresso in late 2012 but the whole issue acquired a new dimension after an interview of Portugal's Foreign Affairs minister, Rui Machete, to Angolan National Radio (RNA) where he presented diplomatic apologies to Luanda and also indicated he had access to privileged information on the matter, which he should not under the Portuguese Constitution

\footnotetext{
${ }^{6}$ Accessed in http://marcolinomoco.com/?p=888 (2013-10-31).

7 Accessed in http://jornaldeangola.sapo.ao/opiniao/artigos/a rtp internacional e a rtp africa no reforco da lingua po rtuguesa (2013-03-13).
} 
(Diário de Notícias, 2013-10-04). The 'faux pas' was met by highly vocal internal requests for his resignation and in contrast by three consecutive supportive editorial pieces in Jornal de Angola. The tone of these texts could be seen as confirmation that this had become a defining moment, especially in putting to rest the "narrative of harmony'. Portuguese elites were portrayed as dishonest, aggressive and racist - "The money grabbing Portuguese elite has entered a period of madness. (...) Angola is always the target of these castaways who cannot get their hands on the money of the ruined Portuguese state"- and the media were presented as an "association of evildoers" (Domingos, 2013-10-06). Using discursive devices like irony and rhetorical questions these texts promoted not only a boisterous condemnation of Portugal's political, judicial, and media systems but also projected onto them, via an alleged attachment to a colonialist pattern of behaviour, the responsibility for the problems in Portugal-Angola relations. Relevantly, the same texts all seem to share one other feature - a reference to a different time and space (no doubt imagined) where the possibility of a fruitful and honourable meeting between 'brothers' might occur. Longer term effects of this highly visible case would be hinted at a few days later during the State of Nation speech by Angolan President, José Eduardo dos Santos: "Unfortunately things are not as well with Portugal; high level misunderstandings have appeared and the present climate advises against the formerly announced construction of a strategic partnership" (Santos, 2013, p. 12).

Multiple diplomatic efforts have been made to appease the situation and, much more in line with what had happened for almost 30 years, relations have in fact come to conform within a realpolitik-induced framework in the following years (Portugal has hence changed government and Angola's attention had to be diverted to a severe economic crisis). Gone were the days of 'harmony' and although both Isabel dos Santos and António Mosquito remain powerful and influential players in Portuguese media Newshold has since all but disappeared from the sector (by the end of 2015 it had sold both Sol and $i$ and maintained only a 2,4\% position at Impresa). Increasingly from 2015 onwards (with the noticeable exception of titles held by Mosquito's Global Media Group) the Portuguese media started to present Angola under a less benign gaze, and visibility was given to issues like human rights abuses, freedom of expression violations, and the contrast between the living standards of the elite and the common Angolan citizen ${ }^{8}$.

It could thus be argued, in a crude attempt at a conclusion, that Angolan capital flow into a debilitated Portuguese media sector in the last decade perhaps failed in its attempt to promote a new-shared image of the relationship between the two countries. If instead we seek more than an oversimplification we could perhaps point out to a few intertwined relevant issues raised by this on-going process.

Firstly, inbound capital flows into depleted economies tend to receive very little political attention; when combined with a lessening of media ownership regulation they can easily lead to unforeseen changes in the media landscape.

Secondly, the combination of favourable neo-liberal policies and strategic 'power politics' presents new challenges to a media regulation system ill prepared for concerted actions by multiple agents.

\footnotetext{
8 The Jornal de Angola editorials mentioned in the beggining of this text were also (at least in part) a 'response' to a SIC television documentary aired in November 2016 with the title: "Angola: a rich country with 20 million poor". Accessed in https://www.youtube.com/watch?v=erNdemyZVGI.
} 
Thirdly, the Portuguese political eagerness to accommodate the wishes of an Angolan elite can be interpreted as the reinforcement of an arrangement with clear colonial overtones; the episodic reference to a 'special culture' of the 'African family' in order to justify pandering to unexplained capital flows further reinforces that stance. As one of the most vocal regime opponents, Rafael Marques de Morais has written: "the real African families have suffered plenty at the hands of leaders who do not hesitate to steal from them" (2016-04-24). In that sense, Portugal's effort to appease Luanda's regime could even be perceived as detrimental to long-term relations between the two countries.

Fourthly, the Angolan regime's insistence on an operative framework whereby governments completely control the media system produces a climate of heightened sensitivity.

Finally, the permanence of such conflicting views empowers a reading, which sees a 'history of resentment' narrative at the heart of all Lusophone constructs, and which cannot avoid reducing diversity to an artificial unity of some sort (Martins, 2011). In so doing it muddles any attempt at creating a post-colonial reframing of the relationship.

\section{References}

AICEP (2016, September). Angola - Ficha de mercado. Accessed in http://www.portugalglobal.pt/PT/Biblioteca/Paginas/Detalhe.aspx?documentId=c394 b4f8-db0b-4d6a-b38c-95ed9a940b5d.

AICEP (2016, December). Relações Económicas Bilaterais com Angola: 2011-2016 (janeiro a outubro. Accessed in http://www.portugalglobal.pt/PT/Biblioteca/Paginas/Detalhe.aspx?documentId=cb9ea bae-9900-4d44-827d-fe39dcd0202b.

André, A. C., Fernandes, J. C. (2015-11-11). Em Angola não há emigrantes. In Sábado. Accessed in http://www.sabado.pt/vida/detalhe/em_angola_nao_ha_emigrantes.html.

Alves, F., Sarmento, A. (2015). Os novos donos disto tudo. Lisboa: matéria-prima.

Ames, P. (2015-04-28). Portugal is becoming an Angolan financial colony. In Politico. Accessed in http://www.politico.eu/article/angola-portugal-investmenteconomy/.

Bayart, J. F. (1993). The State in Africa - The Politics of the Belly. London: Longman.

Candeias, P., Malheiros, J., Marques, J. C., Liberato, E. (2016). A nova emigração para Angola: integração diferenciada e forte ligação a Portugal. In João Peixoto et al. (Eds.), Regresso ao Futuro. A Nova Emigração e a Sociedade Portuguesa, (pp.199233). Lisboa: Gradiva. 
Costa, J., Lopes, J. T., Louçã, F. (2014). Os donos angolanos de Portugal. Lisboa: Bertrand.

Diário de Notícias (2013-10-04). Rui Machete pediu desculpa a Angola. Accessed in http://www.dn.pt/politica/interior/rui-machete-pediu-desculpa-a-angola3459711.html.

Domingos, A. (2013-10-06). Criminosos portugueses contra as suas próprias vítimas. In Jornal de Angola. Accessed in

http://jornaldeangola.sapo.ao/opiniao/artigos/criminosos_portugueses_contra_as_suas _proprias_vitimas.

Figueiras, R., Ribeiro, N. (2013). New global flows of capital in media industries after the 2008 financial crisis: the Angola-Portugal relationship. The International Journal of Press/Politics, 18 (4), pp. 508-524.

Galope, F. (2015-10-29). Angola: o fim da miragem. In Visão. Accessed in http://visao.sapo.pt/actualidade/economia/2015-10-29-Angola-O-fim-da-miragem.

Hayes, L. O. (2016). Angola e os angolanos na imprensa portuguesa (2008-2015). Masters thesis in International Development and Cooperation. Lisbon School of Economics \& Management - Universidade de Lisboa. Accessed in https://www.repository.utl.pt/bitstream/10400.5/12506/1/DM-LOH-2016.pdf.

Henriques, A., Ribeiro, N. (2013-11-04). Mal-estar angolano começou há um ano e tornou-se 'intolerável'. In Público. Accessed in https://www.publico.pt/portugal/jornal/malestar-angolano-comecou-ha-um-ano-etornouse-intoleravel-27348736.

Jornal de Notícias (2012-08-22). Investimento angolano em Portugal cresceu 35 vezes na última década. Accessed in http://www.jn.pt/mundo/palops/interior/investimentoangolano-em-portugal-cresceu-35-vezes-na-ultima-decada-2730510.html.

Martins, M. L. (2011). Crise no Castelo da Cultura. Coimbra: Grácio editor / CECSUMinho.

Morais, R. M. (2016-04-24). Os afectos entre Portugak e Angola e o racismo encapotado. In Maka Angola. Accessed in https://www.makaangola.org/2016/04/osafectos-entre-portugal-e-angola-e-o-racismo-encapotado/.

Nobre, A. (2014-03-22). Media perdem um terço da publicidade em dez anos. In Expresso, Economia, p. 23.

Pombares, C., (2013-10-10). O pedido de desculpas de Rui Machete. In Jornal de Angola. Acessed in http://jornaldeangola.sapo.ao/opiniao/artigos/o_pedido_de_desculpas_de_rui_machet e.

Renascença (2013-07-09). Investimento angolano em Portugal pode valer mais de 6 
mil milhões. Accessed in

http://rr.sapo.pt/informacao_detalhe.aspx?fid=1\&did=113989.

Ribeiro, J. (2016-12-25). Mensagem de harmonia expressa em dia de Natal. In Jornal de Angola. Accessed in

http://jornaldeangola.sapo.ao/opiniao/a_palavra_do_director/mensagem_de_harmonia _expressa_em_dia_de_natal.

Ribeiro, J. (2017-01-01). Desejos para o Novo Ano. In Jornal de Angola. Accessed in http://jornaldeangola.sapo.ao/opiniao/a_palavra_do_director/desejos_para_o_novo_an o.

Santos, J. E. (2013-10-15). Mensagem sobre o Estado da Nação, proferida por Sua Excelência José Eduardo dos Santos, Presidente da República de Angola, na abertura da II Sessão Legislativa da III Legislatura da Assembleia Nacional. Luanda. Accessed in : http://www.mission-angola.ch/discursos/pt/20131015_presidente_pt.pdf.

Silvestre, J., Cruz, O. (2014-03-25). Austeridade tira 29 mil milhões de euros aos portugueses. In Expresso. Accessed in http://expresso.sapo.pt/economia/austeridadetira-29-mil-milhoes-de-euros-aos-portugueses $=\mathrm{f} 862270$.

Sousa, H, Santos, L.A. (2014). Portugal at the eye of the storm: crisis, austerity and the media. In Javnost-The Public, 21 (4), pp. 41-62.

Sparks, C., (2010). China's Media in Comparative Perspective. In International Journal of Communication, 4, pp. 552-566. 